\title{
PERANAN AUDIT OPERASIONAL ATAS PIUTANG USAHA DALAM RANGKA MEMINIMALKAN PIUTANG TAK TERTAGIH PADA PT BINAKARSA SWADAYA
}

\author{
Satsangkaryon \\ Dosen Tetap Fakultas Ekonomi Universitas Pakuan \\ Lecturer of Economic Faculty at Pakuan University \\ Holilah Meliyani \\ Mahasiswa Fakultas Ekonomi Universitas Pakuan \\ Student of Economic Faculty at Pakuan University
}

\begin{abstract}
ABSTRAK
Permasalahan PT. Binakarsa Swadaya lemahnya pengawasan atas piutang usaha yang mengakibatkan meningkatnya penyisihan piutang tak tertagih. Penelitian ini bertujuan: 1) untuk mengetahui pelaksanaan audit operasional atas piutang usaha pada PT. Binakarsa Swadaya; 2) untuk mengetahui upaya-upaya yang dilakukan manajemen PT. Binakarsa Swadaya dalam meminimalkan PT. Binakarsa Swadaya piutang tak tertagih; 3) untuk mengetahui peranan audit operasional atas piutang usaha dalam upaya meminimalkan piutang tak tertagih pada PT. Binakarsa Swadaya. Untuk memudahkan proses analisis, penulis mengklasifikasikan variabel asatu yaitu Peranan Audit Berdasarkan hasil penelitian terhadap penilaian pelaksanaan audit operasional atas piutang usaha pada PT. Binakarsa Swadaya telah diterapkan dengan baik, sedangkan berdasarkan penelitian terhadap meminimalkan piutang tak tertagih pada PT. Binakarsa Swadaya dapat terlihat dari tingkat perputaran piutang usaha selalu menurun setiap tahunnya.
\end{abstract}

Kata Kunci: Perencanaan Audit, Pelaksanaan Audit, Pelaporan, Upaya Meminimalkan, Piutang Tak Tertagih.

\begin{abstract}
Problems at PT. Binakarsa Swadaya is supervisions weakness of trade receivables resulting that made the allowance for doubtful accounts increase. This study aims: 1) to assess the implementation of operational audits on accounts receivable at PT Binakarsa Swadaya; 2) to assess the efforts done by the management of PT. Binakarsa Swadaya in minimizing doubtful accounts PT Binakarsa; 3) to determine the role of the operational audit of accounts receivable in an effort to minimize bad debt at PT. Binakarsa Swadaya. Based on the results of the assessment on the implementation of the operational audit of accounts receivable at PT. Binakarsa Swadaya has been well implemented, while based on a study of minimizing bad debt at PT. Binakarsa Swadaya can be seen from the accounts receivable turnover rate always declines annually.
\end{abstract}

Keywords: Audit Planning, Audit, Reporting, Minimizing Efforts, Doubtful.

\section{Pendahuluan}

Audit operasional atas piutang usaha sangat diperlukan jika pengendalian manajemen penjualan dan piutang dinilai tidak cukup baik, karena audit operasional atas piutang usaha berperan menilai efektivitas dari prosedur operasi manajemen penjualan dan piutang. Yang pada akhirnya akan memberikan rekomendasi kepada manajemen sebagai perbaikan demi kemajuan perusahaan. PT. Binakarsa
Swadaya merupakan perusahaan yang bergerak dalam bidang jasa pengelolaan bangunan dan gedung secara terpadu maupun parsial, kontruksi dan jasa penyediaan dan pengelolaan tenaga kerja termasuk pengamanan, pengemudi, dan perparkiran. Berdasarkan data yang telah dikumpulkan, terlihat bahwa piutang usaha mengalami fluktuasi pada tahun 2008 sampai dengan tahun 2012, sedangkan penyisihan piutang tak tertagih mengalami peningkatan pada 
tahun 2008 sampai dengan 2012. Oleh karena itu tujuan drai penelitian ini adalah sebagai berikut: 1) untuk mengetahui pelaksanaan audit operasional atas piutang usaha pada PT. Binakarsa Swadaya; 2) untuk mengetahui upaya-upaya yang dilakukan manajemen PT. Binakarsa Swadaya dalam meminimalkan PT. Binakarsa Swadaya piutang tak tertagih; 3) untuk mengetahui peranan audit operasional atas piutang usaha dalam upaya meminimalkan piutang tak tertagih pada PT. Binakarsa Swadaya.

\section{Metode Penelitian}

Metode analisi adalah suatu proses penyederhanaan data ke dalam bentuk yang lebih mudah untuk dibaca dan diintrepetasikan dalam bentuk menganalisis permasalahan yang diangkat dan untuk melihat hubungan antara variabel-variabel yang terlibat, maka metode analisis yang digunakan oleh penulis adalah deskriptif kualitatif dan kuantitaif non statistik dengan mengumpulkan data yang relevan yang tersedia yang bersifat kualitatif maupu kuantitatif.

\section{Hasil dan Pembahasan}

3.1. Pelaksanaan Audit Operasional atas Piutang Usaha pada PT Binakarsa Swadaya

Pelasanaan audit operasional atas piutang usaha pada PT. Binakarsa Swadaya selama 5 tahun, 2008 sampai dengan 2012 meliputi indikator:

\section{Perencanaan Audit}

Berdasarkan kriteria atas perencanaan audit diperoleh data dari SPI PT. Binakarsa Swadaya yaitu: a) Sampai dengan tahun 2012 program audit direview dan mendapat persetujuan dari Direktur Utama, termasuk jika da perubahan-perubahan tidak mengalami perubahan; b) Sampai dengan tahun 2012 menetapkan tujuan audit tidak mengalami perubahan; c) Sampai dengan tahun 2012 menetapkan pekerjaan tidak mengalami perubahan.

Berdasarkan uraian di atas dapat disimpulkan bahwa pada tahun 2008 sampai dengan 2012 ketiga kriteria telah terpenuhi dan tidak mengalami perubahan atau tetap, sehingga skor atas perencanaan audit sebesar " 3 " dengan kategori "baik".

2. Pelaksanaan audit

Berdasarkan kriteria atas pelaksanaan audit diperoleh data dari SPI PT. Binakarsa Swadaya, yaitu: a) sampai dengan tahun 2012 mengumpulkan bukti audit yang berhubungan dengan tujuan audit tidak mengalami perubahan; b) sampai dengan tahun 2012 pengujian bukti yang telah diperoleh tidak mengalami perubahan; c) sampai dengan tahun 2012 melakukan pemeriksaan prosedur-prosedur yang berlaku tidak mengalami perubahan. Berdasarkan uraian di atas dapat disimpulkan bahwa pada tahun 2008 sampai dengan tahun 2012 ketiga kriteria telah terpenuhi dan tidak mengalamu perubahan atau tetap. Dengan skor sebesar "3"dengan kategori "baik".

3. Pelaporan

Berdasarkan kriteria atas pelaporan diperoleh data dari SPI PT. Binakarsa Swadaya yaitu : a) laporan yang dibuat oleh SPI jelas mudah dimengerti dan logis. Sampai dengan tahun 2012 laporan nyata, jelas tidak mengalami perubahan; b) Pada tahun 2008 SPI PT. Binakarsa Swadaya menyampaikan hasil audit kepata 
auditee dan Direrktur Utama pada pelaksanaan rapat. Rapat tersebut membahas draft LHA dengan kesimpulan hasil audit yang memuat: temuan, kondisi, kriteria, sebab akibat, rekomendasi dan tanggaoan auditee. Sampai dengan tahun 2012 Audit Internal menyampaikan temuan hasil audit kepada auditee dan Direktur Utama tidak mengalami perubahan; c) laporamn hasil audit pada tahun 2008 mencantumkan berbagai rekomendasi, yang tertera dalam evaluasi kinerja pada tahun 2008 berupa PKAT. Sampai dengan tahun 2012 laporan mencantumkan berbagai rekomendasi tidak mengalami perubahan.

Berdasarkan uraian di atas dapat disimpulkan bahwa pada tahun 2008 sampai dengan tahun 2012 ketiga kriteria telah terpenuhi dan tidak mengalami perubahan atau tetap, dengan skor sebesar " 3 " dengan kategori "baik".

4. Tindak Lanjut

Berdasarkan kriteria di atas diperoleh data dari SPI PT. Binakarsa Swadaya: a) Sampai dengan tahun 2010 Direktur Utama PT. Binakarsa Swadaya belum menetapkan batas waktu tindak lanjut atas rekomendasi. Pada tahun 2011 dan tahun 2012 Direktur Utama PT. Binakarsa Swadaya telsh menetapkan batas waktu tindaklanjut atas rekomendasi audit internal kepada manajemen; b) sampai dengan tahun 2012 rekomendasi yang telah diberikan audit selalu ditindak lanjuti setelah penerbitan laporan hasil audit; c) untuk tahun 2009 sampai dengan tahun 2012 SPI PT. Binakarsa Swadaya telah menilai sejauh mana manajemen mengambil langkah tindak lanjut atas rekomendasi dengan menerima laporan perkembangan perbaikan dari manajemen.

Berdasarkan uraian di atas dapat disimpulkan bahwa tahun 2008 baru memenuhi satu dari ketiga kriteria, sehingga skor penilaian atas tindak lanjut sebesar " 1 " dengan kategori "tidak baik". sedangkan tahun 2009 dan tahun 2010 baru memenuhi dua dari ketiga kriteria sehingga mengalami peningkatan dengan skor "2" dengan kategori "cukup baik", dan untuk tahun 2011 dan tahun 2012 telah mengalami ketiga kriteria sehingga mengalami peningkatan dengan skor "3"dengan kategori "baik".

Tabel 3.1.

Penilaian Pelaksanaan Audit Operasional Assessment Audit Operations

\begin{tabular}{|c|l|c|c|c|c|c|}
\hline \multirow{2}{*}{ No } & \multirow{2}{*}{ Indikator } & \multicolumn{5}{|c|}{ Skor PT. Binakarsa Swadaya } \\
\cline { 3 - 7 } & & 2008 & 2009 & 2010 & 2011 & 2012 \\
\hline 1 & Perencanaan Audit & 3 & 3 & 3 & 3 & 3 \\
\hline 2 & Pelaksanaan Audit & 3 & 3 & 3 & 3 & 3 \\
\hline 3 & Pelaporan & 3 & 3 & 3 & 3 & 3 \\
\hline 4 & Tindak Lanjut & 1 & 2 & 2 & 3 & 3 \\
\hline & Rata-rata indikator & 2,5 & 2,75 & 2,75 & 3 & 3 \\
\hline & Kategori skor & CB & B & B & B & B \\
\hline
\end{tabular}


Berdasarkan tabel diatas dapat disimpulkan rata-rata skor indikator pelaksanaan audit operasional tahun 2008 sebesar " 2,5 " dengan kategori "cukup baik", sedangkan pada tahun 2009 dan 2010 dengan rata-rata skor " 2,75 " dengan kategori "baik", pada tahun 2011 dan tahun 2012 rata-rata skor sebesar " 3 " dengan kategori "baik".

3.2. Meminimalkan Piutang Tak Tertagih pada PT. Binakarsa Swadaya

Tingkat perputaran piutang dapat diperoleh dengan cara:

$$
\text { Tingkat Perputaran Piutang Usaha }=\frac{\text { tingkat penjualan }}{\text { Rata-rata piutang usaha }}
$$

Sedangkan untuk mengukur periode rata-rata pengumpulan piutang dapat diperoleh dengan cara:

$$
\text { Rata-rata Pengumpulan Piutang }=\frac{\text { Jumlah Hari Setahun }(360)}{\text { Tingkat Perputaran Piutang Usaha }}
$$

Tabel 3.2.

Tingkat Perputaran Piutang Usaha dan Rata-Rata Pengumpulan Piutang Accounts Receivable Turnover Rate and Average Receivable Collection

\begin{tabular}{|l|c|c|c|c|}
\hline Tahun & $\begin{array}{c}\text { Total } \\
\text { Penjualan }\end{array}$ & $\begin{array}{c}\text { Rata-Rata } \\
\text { Piutang } \\
\text { Usaha }\end{array}$ & $\begin{array}{c}\text { Tingkat } \\
\text { Perputaran } \\
\text { Piutang Usaha }\end{array}$ & $\begin{array}{c}\text { Rata-Rata } \\
\text { Pengumpulan } \\
\text { Piutang }\end{array}$ \\
\hline 2008 & 6.238 .692 .247 & 1.052 .953 .916 & 5,92 & 60 hari \\
\hline 2009 & 22.126 .659 .264 & 4.061 .476 .368 & 5,44 & 66 hari \\
\hline 2010 & 18.463 .813 .279 & 3.652 .292 .183 & 5,05 & 71 hari \\
\hline 2011 & 24.640 .367 .422 & 5.437 .860 .705 & 4,53 & 79 hari \\
\hline 2012 & 14.533 .111 .100 & 3.942 .237 .473 & 3,68 & 97 hari \\
\hline
\end{tabular}

Berdasarkan tabel di atas terlihat bahwa tingkat perputaran piutang usaha pada tahun 2008 sebesar 5,92 dengan rata-rata pengumpulan piutang 60 hari, pada tahun sebesar 5,44 dengan rata-rata pengumpulan piutang 66 hari, pada tahun 2010 sebesar 5,05 dengan rata-rata pengumpulan piutang 71 hari, pada tahun 2011 sebesar 4,53 dengan rata-rata pengumpulan piutang 79 hari, pada tahun 2012 sebesar 3,68 dengan rata-rata pengumpulan piutang 97 hari.
Berdasarkan idealnya tingkat perputaran piutang usaha yaitu 6 kali dalam setahun, dapat dilihat dari grafik di atas menggambarkan tingkat perputaran piutang usaha pada tahun 2008 cukup baik yaitu 5,92 namun pada tahun 2009 sampai dengan tahun 2012 mengalami penurunan.

\subsection{Peranan Audit Operasional Atas Piutang Usaha Dalam Rangka Meminimalkan Piutang Tak}




\section{Tertagih pada PT. Binakarsa Swadaya}

Adanya peningkatan nilai audit operasional atas piutang usaha yang tidak diikuti dengan meminimalkan

\section{Kesimpulan}

Berdasarkan penelitian terhadap penilaian pelaksanaan audit operasional atas piutang usaha pada PT. Binakarsa Swadaya telah diterapkan dengan baik. hal tersebut dapat dilihat dari nilai pelaksanaan audit operasional atas piutang usaha pada tahun 2008 sampai dengan tahun 2012 mengalami peningkatan yaitu pada tahun 2008 sebesar " 2,5 " dengan kategori "cukup baik", sedangkan pada tahun 2009 dan 2010 dengan rata-rata skor " 2,75 " dengan kategori "baik", pada tahun 2011 dan tahun 2012 rata-rata skor sebesar "3" dengan kategori "baik".

Sedangkan berdasarkan penelitian terhadap meminimalkan piutang tak tertagih pada PT. Binakarsa Swadaya dapat terlihat dari tingkat perputaran piutang usaha pada tahun 2008 cukup baik yaitu 5,92 namun pada tahun 2009 sampai dengan tahun 2012 mengalami penurunan.

Berdasarkan uraian di atas maka dapat disimpulkan bahwa adanya peningkatan nilai audit operasional atas piutang usaha yang tidak diikuti dengan meminimalkan piutang tak tertagih, hal ini menunjukkan bahwa audit piutang tak tertagih, hal ini menunjukan bahwa audit operasional atas piutang usaha tidak berperan dalam meminimalkan piutang tak tertagih pada PT. Binakarsa Swadaya.

operasional atas piutang usaha tidak berperan dalam meminimalkan piutang tak tertagih pada PT. Binakarsa Swadaya.

\section{Daftar Pustaka}

Alvin A. Arens, Randal J. Elder, Mark S. Beasley. 2003. Auditing Dan Pelayanan Verifikasi. Alih Bahasa: Tim Dejacarta. Jilid 1. Edisi Kesembilan. PT. Indeks Kelompok Gramedia. Jakarta.

Drucker, Peter. 2008. Intisari Manajemen, Alih Bahasa Wilson. Bangun Refika Aditama. Bandung. Hery. 2011. Akuntansi: Aktiva, Utang, Dan Modal. Gava Media. Jakarta.

Hongren, Charles T, Walter T. Horisson, Dan Linda Smith Bamber. 2010. Akuntansi. Edisi Keenam. Alih Bahasa: Balian Muhammad. Jilid Satu. PT. Indeks Kelompok Gramedia. Jakarta.

IBK Bayangkara. 2008. Management Audit:Prosedur Dan Implementasi. Salemba Empat. Jakarta.

Sukrisno Agoes. 2012. Auditing Petunjuk Praktis Pemeriksaan Akuntan Oleh Akuntan Publik. Edisi Keempat. Buku Satu. Salemba Empat. Jakarta. 